\title{
Neurohypophysial hormone receptors and second messengers in trout hepatocytes
}

\author{
M E Guibbolini, P M Pierson and B Lahlou \\ Laboratoire de Physiologie Cellulaire et Moléculaire, CNRS UMR 6548, Université de Nice-Sophia Antipolis, Faculté des Sciences-Parc Valrose, \\ 06108 Nice Cedex 2, France \\ (Requests for offprints should be addressed to M E Guibbolini; Email: guibboli@unice.fr)
}

\begin{abstract}
Neurohypophysial hormone receptors and second messengers were studied in trout (Oncorhynchus mykiss) hepatocytes. Arginine vasotocin (AVT) and isotocin (IT) elicited a concentration-dependent inhibition of cAMP accumulation in the presence of $5 \times 10^{-8} \mathrm{M}$ glucagon (maximal effect for $4.5 \times 10^{-7} \mathrm{M}$ and $1.4 \times 10^{-7} \mathrm{M}$, half-maximal effect for $2.1 \times 10^{-8} \mathrm{M}$ and $0.7 \times 10^{-8} \mathrm{M}$, AVT and IT respectively). The effect of glucagon was inhibited up to $90 \%$ by AVT and $80 \%$ by IT. While AVT inhibited (up to $50 \%)$ the basal cAMP production, IT had no such action.

Specific $\mathrm{V}_{1}$ or $\mathrm{V}_{2}$ analogues (with reference to vasopressin in mammals) were used for pharmacological characterization of the type of neurohypophysial hormone receptor involved in this inhibition. The $\mathrm{V}_{1}$ agonist $\left[\mathrm{Phe}^{2}\right.$, $\mathrm{Orn}^{8}$ ]-oxytocin inhibited the glucagon-stimulated cAMP production with a maximal effect for $6 \times 10^{-7} \mathrm{M}$ and a half-maximal effect for $0.9 \times 10^{-8} \mathrm{M}$ concentrations of the analogue. While the $\mathrm{V}_{1}$ agonist reduced the glucagonstimulated cAMP level by $70 \%$, it showed only a tendency to reduce the basal level. The $\mathrm{V}_{2}$ agonist [deamino ${ }^{1}$, $\mathrm{Val}^{4}, \mathrm{D}-\mathrm{Arg}^{8}$ ]-vasopressin had no effect either on basal or on glucagon-stimulated cAMP production. The $\mathrm{V}_{1}$
\end{abstract}

antagonist $\left[\mathrm{d}\left(\mathrm{CH}_{2}\right)_{5}{ }^{1}, \mathrm{O}-\mathrm{Me}-\mathrm{Tyr}^{2}, \mathrm{Arg}^{8}\right]$-vasopressin totally reversed the $10^{-8} \mathrm{M}$ AVT-induced inhibition of $5 \times 10^{-8} \mathrm{M}$ glucagon-stimulated cAMP production, whereas the $\mathrm{V}_{2}$ antagonist $\left[\mathrm{d}\left(\mathrm{CH}_{2}\right)_{5}{ }^{1}, \mathrm{D}-\mathrm{Ile}^{2}, \mathrm{Ile}^{4}, \mathrm{Arg}^{8}\right.$, $\left.\mathrm{Ala}^{9}\right]$-vasopressin had no such effect. In this particular case, maximal and half-maximal effects of the $\mathrm{V}_{1}$ antagonist were obtained for $2.3 \times 10^{-6} \mathrm{M}$ and $1.2 \times 10^{-6} \mathrm{M}$ respectively.

Changes in intracellular calcium content were measured using the fluorescent probe FURA-2/AM. AVT and IT elicited a concentration-dependent increase in $\mathrm{Ca}^{2+}$ accumulation. The comparison of the effect of $10^{-8} \mathrm{M}$ agonists versus AVT showed the following order of potency: $A V T=I T>V_{1}$ agonist $>V_{2}$ agonist. The $V_{1}$ antagonist reversed the AVT-induced $\mathrm{Ca}^{2+}$ accumulation whereas the $V_{2}$ antagonist had no such effect.

These results are taken as evidence for the presence in trout hepatocytes of neurohypophysial hormone receptors functionally close to the $\mathrm{V}_{1 \mathrm{a}}$-type linked to cAMP production and $\mathrm{Ca}^{2+}$ mobilization.

Journal of Endocrinology (2000) 167, 137-144

\section{Introduction}

In mammals, vasopressin (AVP) possesses a glycogenolytic effect and its mechanism of action has been well defined in hepatocytes. In the rat, labelled AVP binds to specific receptors located on intact cells or isolated membranes and coupled to a G protein (Cantau et al. 1980, Fitzgerald et al. 1986). This receptor was pharmacologically characterized as a $V_{1 a}$-type (Fahrenholz et al. 1984, Sato et al. 1992); it was recently cloned and shown to possess seven transmembrane domains (Morel et al. 1992, 1993). The $\mathrm{V}_{1 \mathrm{a}}$ receptor was shown to mediate vasopressin-induced glycogenolytic responses by enhancing polyphosphoinositide breakdown and by increasing inositol triphosphate $\left(\mathrm{IP}_{3}\right)$ and diacylglycerol (DAG) (Thomas et al. 1984, Cerpovicz $\&$ Ochs 1992). The $\mathrm{IP}_{3}$ formed induces an increase in the concentration of intracellular ionic calcium (Thomas et al. 1984) due to the liberation of calcium from intracellular stores (Hajnoczky \& Thomas 1997) and sustained by an extracellular calcium influx (Garrison et al. 1979, Berven et al. 1994, Duszynski et al. 1995). DAG activates a protein kinase C (Tang \& Houslay 1992). The intervention of protein kinases leads to protein phosphorylation (Morris et al. 1994) and to activation of mitogen-activated protein kinase (Romanelli \& Van de Werve 1997). Another effect of vasopressin is to inhibit, in a dose-dependent manner, the cAMP accumulation induced by forskolin or glucagon whether cells are depleted in calcium or not (Morgan et al. 1983).

In amphibian hepatocytes, arginine vasotocin (AVT) or AVP (the heterologous hormone, generally used) produces a dose-dependent stimulation of glycogenolysis (Janssens 
et al. 1983, Ade et al. 1995) mediated by cAMP accumulation (Janssens et al. 1986) and not by $\mathrm{IP}_{3}$ production (Kleineke \& Janssens 1993). Kleineke and Janssens (1993) showed that AVT induced an increase in intracellular concentration of calcium, directly due to an extracellular calcium influx. They concluded that AVT stimulated cAMP production which not only induced glycogenolysis but also regulated the opening of an ionic channel allowing calcium influx. The stimulatory effect of AVT on cAMP accumulation and the pharmacological study carried out on primary cultures of Xenopus laevis hepatocytes led authors to classify this receptor as a $\mathrm{V}_{2}$-type receptor (Ade et al. 1995).

In contrast to other vertebrates, little is known in fish concerning the mechanism of action of neurohypophysial peptides on hepatocytes (Lahlou et al. 1988, Moon \& Mommsen 1990). Moon and Mommsen (1990) showed that neurohypophysial peptides activated the glycogenolysis in eel and to a lesser extent in trout liver. In the same study, AVT induced in eel a dose-dependent stimulation of cAMP concentration. However, the concentrations of AVT used in their study were relatively high $\left(10^{-7}\right.$ to $10^{-5} \mathrm{M}$ ). In contrast, Lahlou et al. (1988) showed in the trout that neurohypophysial peptides at concentrations of $5 \times 10^{-7}$ to $5 \times 10^{-6} \mathrm{M}$ (concentrations also relatively high) inhibited the cAMP accumulation stimulated by $4 \times 10^{-8} \mathrm{M}$ glucagon (Lahlou et al. 1988).

Taken together, these data led us to investigate further the mechanism of action of neurohypophysial peptides in trout hepatocytes. The aim of the present study was (1) to analyse the nature of second messengers (cAMP and $\mathrm{Ca}^{2+}$ ) involved in the transduction of the neurohypophysial peptide effect, and (2) to characterize pharmacologically the type(s) of peptide receptor(s) present in trout hepatocytes by using selected specific $V_{1}$ or $V_{2}$ analogues. Results are considered with regard to the phylogenic evolution of neurohypophysial peptide receptors in the vertebrate series.

\section{Materials and Methods}

\section{Animals}

Rainbow trout, Oncorhynchus mykiss (average weight $220 \mathrm{~g}$ ), were purchased from a fish farm and maintained in the laboratory at $12-15^{\circ} \mathrm{C}$, under constant photoperiod (12 h light per day).

\section{Chemicals}

Pure arginine vasotocin (AVT), isotocin (IT) and vasopressin analogues were obtained from Bachem (Torrance, CA, USA). The following analogues were selected for their high pharmacological specificity in mammals, as established by Manning and colleagues (Manning \&
Sawyer 1984, Manning et al. 1993): [Phe², $\left.\mathrm{Orn}^{8}\right]-$ oxytocin ( $\mathrm{V}_{1 \mathrm{a}}$ agonist), [deamino $\left.{ }^{1}, \mathrm{Val}^{4}, \mathrm{D}^{\mathrm{A}} \mathrm{Arg}^{8}\right]-$ vasopressin $\left(\mathrm{V}_{2}\right.$ agonist), [d $\left.\left(\mathrm{CH}_{2}\right)_{5}{ }^{1}, \mathrm{O}-\mathrm{Me}-\mathrm{Tyr}^{2}, \mathrm{Arg}^{8}\right]-$ vasopressin $\left(\mathrm{V}_{1 \mathrm{a}}\right.$ antagonist $),\left[\mathrm{d}\left(\mathrm{CH}_{2}\right)_{5}{ }^{1}, \mathrm{D}-\mathrm{Ile}^{2}, \mathrm{Ile}^{4}, \mathrm{Arg}^{8}\right.$, $\left.\mathrm{Ala}^{9}\right]$-vasopressin ( $\mathrm{V}_{2}$ antagonist). HANK's minimum essential medium (HMEM), bovine serum albumin fraction $\mathrm{V}$ (BSA) and collagenase $\mathrm{H}$ were obtained from Boehringer Mannheim (Illkirch, France) and heparin LEO (5000 UI/ml) from LEO Laboratory (St-Quentinles-Yvelines, France). Glucagon was supplied by NOVO Nordisk Pharmaceutique S.A. (Boulogne, France). Theophylline (cAMP phosphodiesterase inhibitor) was purchased from Sigma-Aldrich Chimie (L'Isle d'Abeau Chesnes, France). FURA-2/AM and pluronic acid were obtained from Molecular Probes (Interchim, France). The $\left[{ }^{3} \mathrm{H}\right]$ cAMP radioimmunoassay kit was obtained from Amersham (Les Ulis, France).

\section{Preparation of hepatocytes}

The basic technique has been described previously (Porthé-Nibelle \& Lahlou 1981). Briefly, the trout liver was perfused via the portal vein for 5 min with a perfusion buffer (in $\mathrm{mM}: \mathrm{NaCl} 66, \mathrm{KCl} 66$, glucose $5 \cdot 5$, Hepes 10 , $\mathrm{pH} 7 \cdot 4)$ and then for $1 \mathrm{~h}$ with collagenase $(0.8 \mathrm{mg} / \mathrm{ml}$ perfusion buffer). Hepatocytes were then collected after 2 passages through a 3-layer gauze, rinsed twice with perfusion buffer and re-suspended in HMEM (300 mosmol/1; pH 7.4). Under these conditions, the intracellular ion concentrations in the isolated cells are not in steady state, although they are viable at room temperature. Consequently, the cells were then preincubated for $40 \mathrm{~min}$ in HMEM prior to use. This treatment restores and stabilizes the cellular electrolyte concentrations for several hours (Lahlou et al. 1988). Cell viability was checked using $0.04 \%$ Trypan blue and preparations containing more than 15\% stained cells were discarded.

\section{Incubation procedure and $C A M P$ determination}

The basic technique has been described previously by Lahlou et al. (1988). Routinely, the typical incubation medium contained $10 \mathrm{mM}$ theophylline and 5\% (w/v) BSA in HMEM, pH 7.4. The final volume was $200 \mu \mathrm{l}$ containing $100 \mu \mathrm{l}$ equilibrated cell preparation (on average: $3.5 \times 10^{6}$ cells or $0.6 \mathrm{mg}$ protein $/ 100 \mu \mathrm{l}$ cell preparation) in HMEM and $20 \mu$ hormone(s). Because inhibitions are often larger or better revealed when the target system is stimulated by another hormone (Guibbolini \& Lahlou 1987, Lahlou et al. 1988), $5 \times$ $10^{-8} \mathrm{M}$ glucagon were added to the incubation medium. When hormones and analogues were considered together in the assay, they were added simultaneously in the incubation medium. The reaction was initiated by addition of the cells which were left to incubate for $10 \mathrm{~min}$ 
at $20{ }^{\circ} \mathrm{C}$ under gentle shaking, and was terminated by 3 min heating in boiling water. Samples taken in duplicate were then centrifuged at $1600 \mathrm{~g}$ for $10 \mathrm{~min}$ at $4{ }^{\circ} \mathrm{C}$, and the supernatants were collected for cAMP measurement. The levels of cAMP were determined in each sample using a $\left[{ }^{3} \mathrm{H}\right]$ cAMP radioimmunoassay kit as specified by the supplier. Protein quantities were determined in each sample by using the method of Bradford (1976).

Results were expressed as pmoles cAMP/mg protein per $10 \mathrm{~min}$ or as a ratio (test/basal, i.e. in the presence/ absence of hormone). Because of variations between individual cell preparations, cAMP content was also expressed as a percentage of maximum (the 100\% value was that obtained with $5 \times 10^{-8} \mathrm{M}$ glucagon alone).

Results were expressed as means \pm s.E., for $n$ independent liver preparations (with each test carried out in duplicate or in triplicate). Statistical significance was determined using the Student's $t$-test applied to comparison between unpaired values, and comparison of means using ANOVA single factor-factorial test (Statview software, Brain Power Inc., Calabasas, CA, USA).

\section{Calcium measurement}

All subsequent operations were carried out at $20{ }^{\circ} \mathrm{C}$ in the dark and under slow shaking. Cell suspensions $\left(2 \times 10^{7}\right.$ cells in $2 \mathrm{ml}$ HMEM) were incubated for $1 \mathrm{~h}$ loading in the presence of FURA-2/AM $(5 \mu \mathrm{M})$ and pluronic acid $(0 \cdot 05 \%)$. After this incubation period, cells were rinsed twice with HMEM $(200 \boldsymbol{g}, 20 \mathrm{~s})$, re-suspended in $2 \mathrm{ml}$ HMEM and left to stabilize for $45 \mathrm{~min}$. Changes in intracellular concentration of calcium $\left(\left[\mathrm{Ca}^{2+}\right]_{\mathrm{i}}\right)$ were measured in $1.5 \mathrm{ml}$ hepatocyte suspension in the presence or absence of hormone(s) (15 $\mu \mathrm{l}$ added), using a PerkinElmer spectrofluorimeter. The fluorescence emission of FURA 2, induced by excitation at two wavelengths (340 and $380 \mathrm{~nm}$ ), was recorded at $510 \mathrm{~nm}$. The fluorescence ratio (F340/F380) was used as an indicator of the variations of $\left[\mathrm{Ca}^{2+}\right]_{\mathrm{i}}$. In these experiments, increasing hormone concentrations were successively added to the cell suspension. Therefore, the fluorescence ratios obtained represent cumulative responses. For each hormone concentration, the experiment was followed for $2 \cdot 5 \mathrm{~min}$ ( 5 cycles of $30 \mathrm{~s}$ ) at room temperature. Maximal effect was obtained between 2 and $2.5 \mathrm{~min}$. Results were expressed as test vs basal ratio, means \pm s.e. ( $n$ independent preparations). Statistical significance of peptide effects on fluorescence ratios in cell preparations was assessed by using repeated measures ANOVA (SYSTAT 5·2.1 software, Systat Inc., NY, USA). This model was carried out since each cell preparation was submitted to increasing concentrations of AVT, IT or analogues. In addition, for AVT and IT analysis, since the sphericity assumption was not checked, $P$ values were corrected using the Greenhouse-Geisser adjustment.

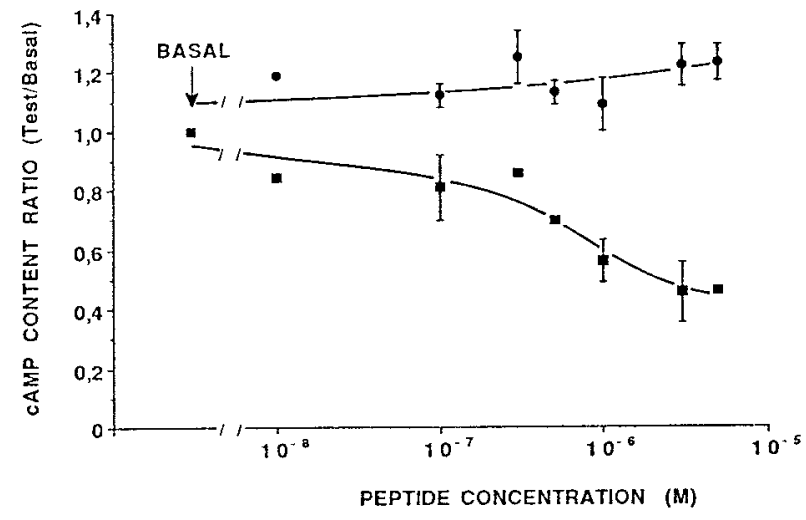

Figure 1 Effect of AVT $(\boldsymbol{\square})$ and IT $(\bullet)$ concentrations on basal CAMP content in trout hepatocytes. Results are means \pm S.E. $(n=3$ for AVT and $n=3$ for IT) and are expressed as test vs basal cAMP ratio. Statistical significance was determined using ANOVA. For $\mathrm{AVT}$, mean values were significantly different from basal for concentrations $\geq 5 \times 10^{-7} \mathrm{M}(P<0 \cdot 05)$. IT values were not significantly different from basal. Error bars are not indicated when smaller than the symbol.

\section{Results}

\section{cAMP measurements}

Effects of hormones The basal cAMP content in hepatocytes was $2.9 \pm 0.6$ pmoles $\mathrm{cAMP} / \mathrm{mg}$ protein per $10 \mathrm{~min}(n=14)$. The effects of AVT and IT in relation to their concentration are illustrated in Fig. 1. In this case, the level of cAMP, as expressed by the test vs basal ratio, was decreased by AVT in a dose-dependent manner. Maximal $\left(\mathrm{D}_{\max }\right)$ and half-maximal $\left(\mathrm{IC}_{50}\right)$ inhibitions were obtained for $3 \cdot 0 \pm 1 \cdot 4 \times 10^{-6} \mathrm{M}$ and $4.5 \pm 2 \cdot 3 \times 10^{-7} \mathrm{M}$ concentrations of the peptide $(n=3)$. While AVT inhibited (up to 50\%) basal cAMP production, IT had no significant effect.

The effects of AVT and IT were studied in the presence of $5 \times 10^{-8} \mathrm{M}$ glucagon and the results are shown in Fig. 2 . We have previously shown that this concentration of glucagon was sufficient to yield an accurately measurable increase in cAMP (Lahlou et al. 1988). In the present experiments, $5 \times 10^{-8} \mathrm{M}$ glucagon stimulated cAMP accumulation by a factor of $3 \cdot 9 \pm 0 \cdot 7(n=14)$ for an average absolute cAMP level of $11 \cdot 3 \pm 3 \cdot 2$ pmoles $\mathrm{cAMP} / \mathrm{mg}$ protein per $10 \mathrm{~min}(n=14)$. In these conditions, both peptides elicited a concentration-dependent inhibition of cAMP accumulation. For AVT, the maximum effect was obtained with $4.5 \pm 2 \cdot 1 \times 10^{-7} \mathrm{M}$ and the half-maximum effect was obtained with $2 \cdot 1 \pm 3 \cdot 4 \times 10^{-8} \mathrm{M}(n=7)$; for IT, $\mathrm{D}_{\max }$ was $1 \cdot 4 \pm 1 \cdot 0 \times 10^{-7} \mathrm{M}$ and $\mathrm{IC}_{50}$ was $0 \cdot 7 \pm 0.35 \times 10^{-8} \mathrm{M}$ $(n=3)$. Stimulation by glucagon was inhibited up to $90 \%$ by AVT and $80 \%$ by IT.

Effects of synthetic analogues Specific $V_{1}$ and $V_{2}$ analogues were used to relate the AVT effect to the 

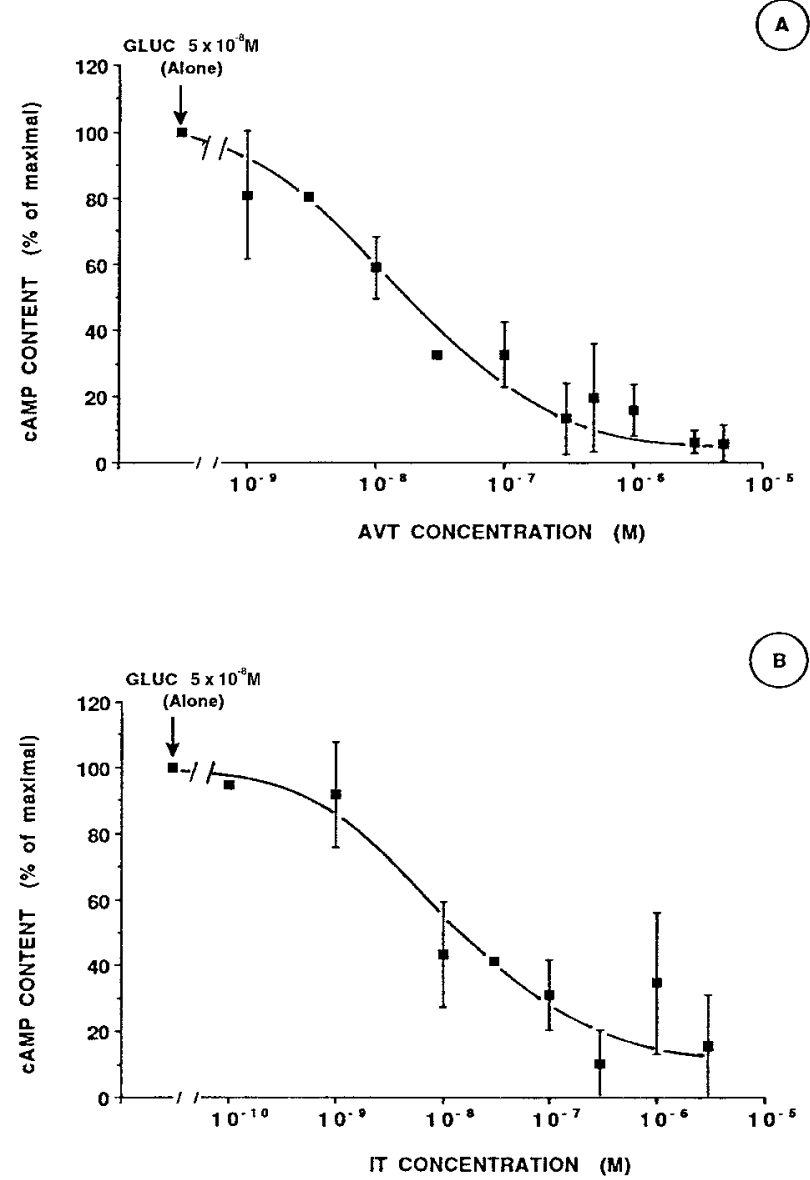

Figure 2 Effect of (A) AVT and (B) IT concentrations on $5 \times 10^{-8} \mathrm{M}$ glucagon-stimulated cAMP accumulation in trout hepatocytes. Results are means \pm S.E. $(n=7$ for AVT and $n=3$ for IT) and are expressed as percentages of maximal effect. The maximal effect (taken as $100 \%$ ) was that obtained with $5 \times 10^{-8} \mathrm{M}$ glucagon alone. Statistical significance was determined using ANOVA. For AVT, mean values were significantly different from glucagon alone between $10^{-8}$ and $5 \times 10^{-6} \mathrm{M}(P<0 \cdot 01)$. For IT, mean values were significantly different from glucagon alone for $10^{-8} \mathrm{M}$ and $3 \times 10^{-8} \mathrm{M}(P<0.05)$ and between $10^{-7}$ and $3 \times 10^{-6} \mathrm{M}(P<0 \cdot 01)$. Error bars are not indicated when smaller than the symbol.

presence of receptors functionally close to $\mathrm{V}_{1}$ and/or $\mathrm{V}_{2}$ type(s).

Agonists The effects of the $\mathrm{V}_{1}$ and $\mathrm{V}_{2}$ agonists on basal (Table 1) and on $5 \times 10^{-8} \mathrm{M}$ glucagon-stimulated cAMP production (Fig. 3) revealed that the $\mathrm{V}_{1}$ agonist inhibited the glucagon-stimulated activity with maximal and halfmaximal inhibitions obtained for $6.0 \pm 2.7 \times 10^{-7} \mathrm{M}$ and $0 \cdot 9 \pm 0 \cdot 4 \times 10^{-8} \mathrm{M}$ concentrations of the analogue $(n=6)$. While the $V_{1}$ agonist reduced the glucagon-stimulated level of cAMP by $70 \%$, it only showed a slight, not significant tendency to reduce the basal level. The $\mathrm{V}_{2}$
Table 1 Effect of the $V_{1}$ agonist ([Phe $\left.{ }^{2}, \mathrm{Orn}^{8}\right]$-oxytocin) and the $\mathrm{V}_{2}$ agonist ([deamino $\left.{ }^{1}, \mathrm{Val}^{4},{ }^{4} \mathrm{D}-\mathrm{Arg}^{8}\right]$-vasopressin) concentrations on basal cAMP content in trout hepatocytes. Results (means \pm S.E., $n=4$ for the $V_{1}$ agonist and $n=3$ for the $V_{2}$ agonist) are expressed as percentage of basal cAMP content

\begin{tabular}{|c|c|c|}
\hline & $\mathrm{V}_{1}$ agonist $(\%)$ & $\mathrm{V}_{2}$ agonist $(\%)$ \\
\hline Basal Agonist & 100 & 100 \\
\hline $10^{-9} \mathrm{M}$ & $94 \pm 7$ & $90 \pm 21$ \\
\hline $10^{-8} \mathrm{M}$ & $78 \pm 14$ & $95 \pm 11$ \\
\hline $10^{-7} \mathrm{M}$ & $78 \pm 13$ & $83 \pm 15$ \\
\hline $10^{-6} \mathrm{M}$ & $75 \pm 14$ & $99 \pm 32$ \\
\hline
\end{tabular}

Values were not statistically significantly different from basal (ANOVA).

agonist produced no effect in any of the experimental conditions.

Antagonists The concentration of $10^{-8} \mathrm{M}$ AVT was chosen in this set of experiments because it corresponds to the $\mathrm{IC}_{50}$ of this hormone challenging the effect of $5 \times 10^{-8} \mathrm{M}$ glucagon (Fig. 2A). The $\mathrm{V}_{1}$ antagonist was able to reverse totally the inhibition caused by $10^{-8} \mathrm{M}$ AVT on the $5 \times 10^{-8} \mathrm{M}$ glucagon-stimulated production of cAMP (Fig. 4A). Maximal and half-maximal effects of the $\mathrm{V}_{1}$ antagonist were obtained with $2.3 \pm 0.8 \times 10^{-6} \mathrm{M}$ and $1 \cdot 2 \pm 0 \cdot 6 \times 10^{-6} \mathrm{M}$, respectively $(n=6)$. In contrast, the $\mathrm{V}_{2}$ antagonist (Fig. 4B) did not produce this effect, and even showed a slight tendency to decrease further the glucagon-stimulated/AVT-inhibited cAMP accumulation. This tendency was noted for $10^{-8} \mathrm{M} \mathrm{V}_{2}$ analogue only and was not reproduced at higher concentrations.

\section{$\mathrm{Ca}^{2+}$ measurements}

The results we obtained with cAMP led us to undertake experiments on $\mathrm{Ca}^{2+}$, the other main second messenger. Data concerning the effect of the neurohypophysial peptides on $\mathrm{Ca}^{2+}$ mobilization are illustrated in Fig. 5. AVT and IT (in the range of $10^{-10}$ to $10^{-6} \mathrm{M}$ ) elicited an increase in intracellular $\mathrm{Ca}^{2+}$ content in hepatocytes. The analysis of the responses of these two peptides showed that AVT and IT exerted a similar dose-dependent effect on $\mathrm{Ca}^{2+}$ increase.

The use of the same neurohypophysial peptide analogues as in the cAMP measurements gave results summarized in Table 2. For the same concentration as AVT $\left(10^{-8} \mathrm{M}\right)$, the $\mathrm{V}_{1}$ agonist also increased the intracellular $\mathrm{Ca}^{2+}$ ratio significantly from the basal level. The $\mathrm{V}_{2}$ agonist had a less pronounced effect than the $V_{1}$ agonist. The $\mathrm{V}_{1}$ antagonist reversed the AVT effect on $\mathrm{Ca}^{2+}$ accumulation whereas the $V_{2}$ antagonist had no such effect.

\section{Discussion}

The present investigation shows, first, that fish neurohypophysial hormones elicit a dose-dependent inhibition of 

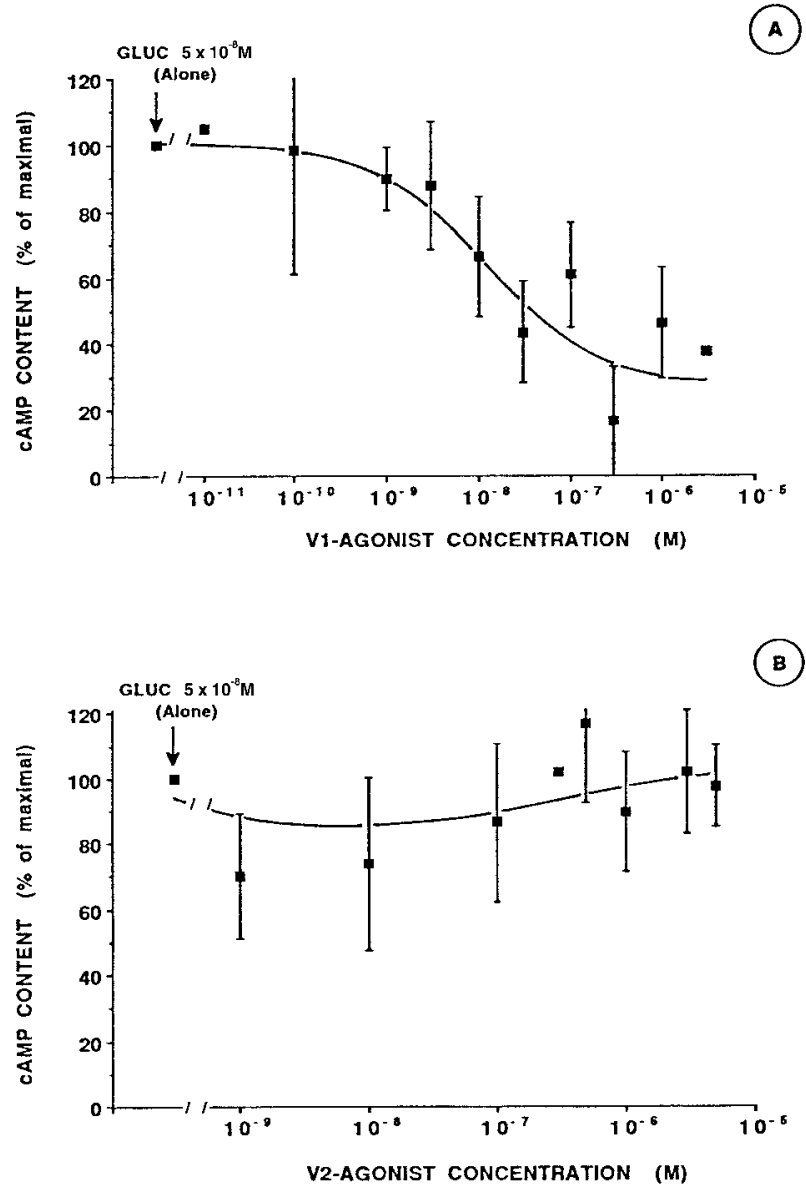

Figure 3 Effect of $(\mathrm{A})$ the $\mathrm{V}_{1}$ agonist ([Phe $\left.{ }^{2}, \mathrm{Orn}^{8}\right]$-oxytocin) and (B) the $\mathrm{V}_{2}$ agonist ([deamino $\left.{ }^{1}, \mathrm{Val}^{4}, \mathrm{D}^{\mathrm{A}} \mathrm{Arg}^{8}\right]$-vasopressin) concentrations on $5 \times 10^{-8} \mathrm{M}$ glucagon-stimulated cAMP accumulation in trout hepatocytes. Results are means \pm S.E. $(n=6$ for the $\mathrm{V}_{1}$ agonist and $n=7$ for the $\mathrm{V}_{2}$ agonist) and are expressed as percentages of maximal effect. The maximal effect (taken as $100 \%$ ) was that obtained with $5 \times 10^{-8} \mathrm{M}$ glucagon alone.

Statistical significance was determined using ANOVA. For the $V_{1}$ agonist, mean values were significantly different from glucagon alone between $3 \times 10^{-8}$ and $3 \times 10^{-6} \mathrm{M}(P<0 \cdot 05)$. The $\mathrm{V}_{2}$ agonist values were not statistically significantly different from glucagon alone. Error bars are not indicated when smaller than the symbol.

cAMP accumulation in trout hepatocytes which is strikingly revealed in the presence of $5 \times 10^{-8} \mathrm{M}$ glucagon. The stimulation by glucagon was decreased up to $90 \%$ by AVT and $80 \%$ by IT, for an AVT or IT concentration of $4.5 \pm 2 \cdot 1 \times 10^{-7} \mathrm{M}(n=7)$ and $1 \cdot 4 \pm 1 \cdot 0 \times 10^{-7} \mathrm{M}(n=3)$, respectively. In rat liver, $10^{-8} \mathrm{M}$ vasopressin used in similar conditions was only able to reduce by $16 \%$ the cAMP accumulation induced by $10^{-8} \mathrm{M}$ glucagon (Morgan et al. 1983). In rat brain, vasopressin was found partially to prevent the cAMP accumulation induced by noradrenaline, dopamine and forskolin $(50 \%, 45 \%$ and $40 \%$ by $3 \times 10^{-7}, 5.5 \times 10^{-7}$ and $3 \times 10^{-7} \mathrm{M}$ AVP respectively,
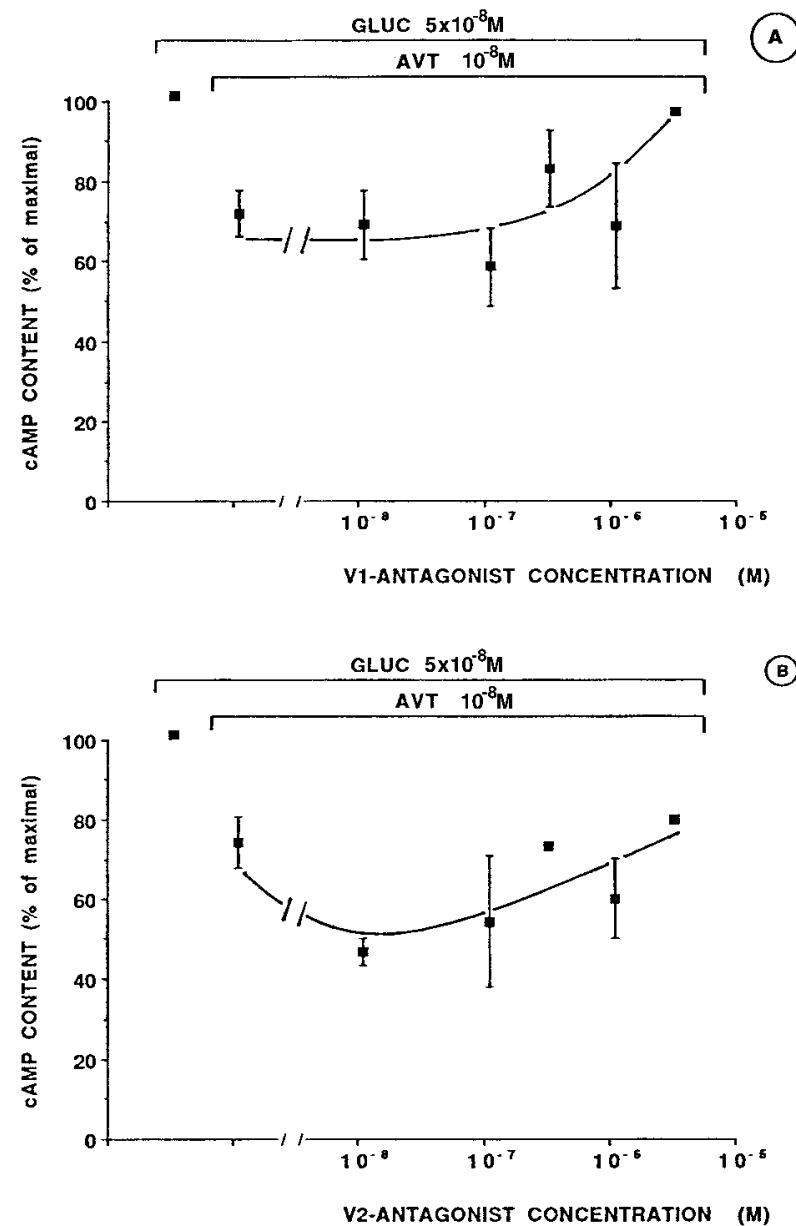

Figure 4 Effect of $(A)$ the $\mathrm{V}_{1}$ antagonist $\left(\left[\mathrm{d}\left(\mathrm{CH}_{2}\right)_{5}{ }^{1}, \mathrm{O}-\mathrm{Me}-\mathrm{Tyr}{ }^{2}\right.\right.$, $\left.\mathrm{Arg}^{8}\right]$-vasopressin) and (B) the $\mathrm{V}_{2}$ antagonist $\left(\left[\mathrm{d}\left(\mathrm{CH}_{2}\right)_{5}{ }^{1}, \mathrm{D}-\mathrm{Il}^{2}, \mathrm{Il}^{4}\right.\right.$, $\left.\mathrm{Arg}^{8}, \mathrm{Ala}^{9}\right]$-vasopressin) concentrations on trout hepatic cellular CAMP production stimulated by $5 \times 10^{-8} \mathrm{M}$ glucagon and inhibited by $10^{-8} \mathrm{M}$ AVT. Results are means \pm S.E. $\left(n=6\right.$ for the $\mathrm{V}_{1}$ antagonist and $n=5$ for the $V_{2}$ antagonist) and are expressed as percentages of maximal effect. The maximal effect (taken as 100\%) was that obtained with $5 \times 10^{-8} \mathrm{M}$ glucagon alone. ANOVA was used to determine the statistical significance of the effects of the antagonists on the inhibitory action of AVT on glucagon-stimulated CAMP production $\left(P<0.05\right.$ for $3 \times 10^{-6} \mathrm{M} \mathrm{V}_{1}$ antagonist and $10^{-8} \mathrm{MV}_{2}$ antagonist). Student's $t$-test applied to comparison of unpaired values was used to compare the AVT effect on glucagon-stimulated cAMP production with that of glucagon alone $(P<0.001$ and $P<0.005$ for curves $A$ and $B$ respectively). Error bars are not indicated when smaller than the symbol.

Newman 1985). In our study, not only did the neurohypophysial peptides strongly inhibit the stimulatory effect, but the basal activity (Fig. 1) was also reduced by AVT (50\% inhibition), a fact only observed in a few cases: 15-25\% inhibition in human platelets (Vanderwel et al. 1983), 40\% in trout gill plasma membranes (Guibbolini \& Lahlou 1987). Secondly, in our model, not only did AVT and IT decrease cAMP production but they also behaved 

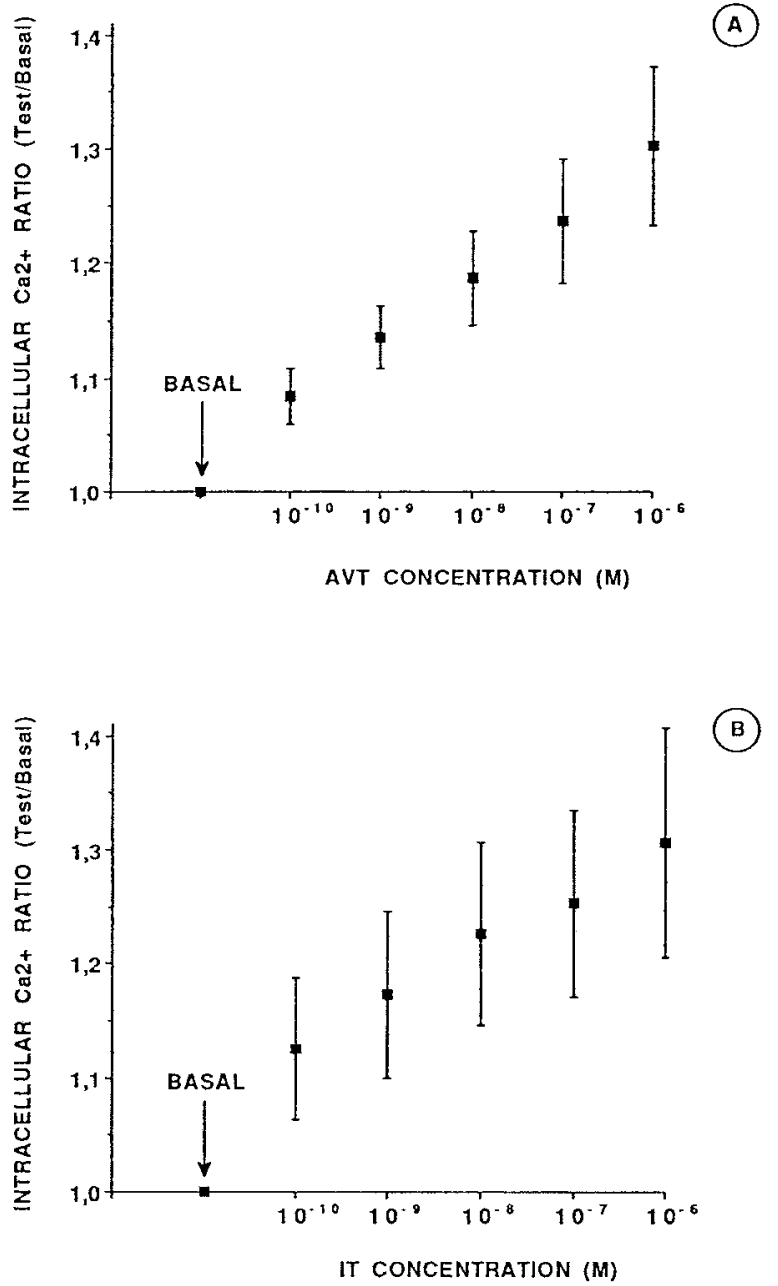

Figure 5 Effect of (A) AVT and (B) IT concentrations on intracellular $\mathrm{Ca}^{2+}$ content in trout hepatocytes. Results are means \pm S.E. ( $n=6$ for AVT and $n=6$ for IT) and are expressed as test vs basal ratio. The dose effect is statistically significant at $0 \cdot 01$ for AVT and at 0.05 for IT (repeated measures ANOVA, Greenhouse-Geisser $P$ value of 0.011 for AVT and 0.027 for IT).

like $\mathrm{Ca}^{2+}$-mobilizing hormones, as do homologous peptides in rat hepatocytes (Thomas et al. 1984, Hajnoczky \& Thomas 1997). To our knowledge, the present study is the first showing an effect of IT on second messenger production in fish hepatocytes.

In the present study, neurohypophysial hormones inhibited glucagon-stimulated cAMP accumulation with $\mathrm{IC}_{50}$ values of around $10^{-8} \mathrm{M}$. With regard to circulating hormone levels, those of neurohypophysial peptides have been estimated only recently in fish (Perrott et al. 1991, Balment et al. 1993, Warne et al. 1994, Pierson et al. $1995 a, b)$. Our present observations are consistent with our own estimates since, in plasma of trout adapted to various degrees of salinity, AVT and IT measured by ELISA were in the range of $8-26 \mathrm{nM}$ and $3-5 \cdot 5 \mathrm{nM}$ respectively
Table 2 Effect of the $V_{1}$ and $V_{2}$ vasopressin receptor agonists and antagonists on calcium content in trout hepatocytes. Results (means \pm S.E. of $n$ experiments) are expressed as test vs basal ratio.

\begin{tabular}{ll} 
& $\begin{array}{l}\text { Intracellular } \\
\mathbf{C a}^{2+} \text { ratio } \\
(\text { test/basal })\end{array}$ \\
\cline { 2 - 2 } Basal & 1 \\
AVT $\left(10^{-8} \mathrm{M}\right)$ & $1 \cdot 187 \pm 0 \cdot 041(n=6)^{* *}$ \\
$\mathrm{~V}_{1}$ agonist $\left(10^{-8} \mathrm{M}\right)$ & $1 \cdot 133 \pm 0 \cdot 027(n=4)^{*}$ \\
$\mathrm{~V}_{2}$ agonist $\left(10^{-8} \mathrm{M}\right)$ & $1 \cdot 070 \pm 0 \cdot 010(n=3)$ \\
AVT $\left(10^{-8} \mathrm{M}\right)+\mathrm{V}_{1}$ antagonist $\left(10^{-6} \mathrm{M}\right)$ & $1 \cdot 036 \pm 0 \cdot 023(n=3)^{\#}$ \\
AVT $\left(10^{-8} \mathrm{M}\right)+\mathrm{V}_{2}$ antagonist $\left(10^{-6} \mathrm{M}\right)$ & $1 \cdot 118 \pm 0 \cdot 010(n=3)$ \\
& \\
${ }^{*} P<0 \cdot 05,{ }^{* *} P<0 \cdot 01$ compared with basal; ${ }^{\#} P<0 \cdot 05$ compared with AVT \\
(repeated measures ANOVA).
\end{tabular}

(Pierson et al. 1995a,b). Furthermore, neurohypophysial hormone $\mathrm{IC}_{50}$ values in the present study are in agreement with $K_{\mathrm{d}}$ values found in binding experiments in rat intact hepatocytes for AVP (15 nM, Cantau et al. 1980) and in eel isolated gill cells for AVT (3.2 to $1 \mathrm{nM}$ in fresh- and sea-water-adapted fish respectively, Guibbolini et al. 1988).

The use of vasopressin analogues for pharmacological characterization of neurohypophysial peptide receptors may be extended with some caution to non-mammalian vertebrates. Several investigators used this approach in amphibians (Larcher et al. 1992, Butlen et al. 1993) and fishes (Pang \& Furspan 1984, Guibbolini \& Lahlou 1990, Uchiyama \& Murakami 1994, Pierson et al. 1996). The present study is the first attempt to characterize the neurohypophysial hormone receptor in fish hepatocytes by means of artificial analogues. The $\mathrm{V}_{1}$ agonist presented a slight tendency to act in a similar manner to AVT on basal cAMP levels, for concentrations within the range of those of AVT and IT. When cAMP accumulation was stimulated by glucagon, the $\mathrm{D}_{\max }$ for AVT, IT and $\mathrm{V}_{1}$ agonist decreased to a similar lower value of $1-6 \times 10^{-7} \mathrm{M}$ and the $\mathrm{IC}_{50}$ for AVT, IT and $\mathrm{V}_{1}$ agonist followed a similar pattern. When the $V_{1}$ antagonist was added, it totally suppressed the AVT-induced inhibition of the glucagonstimulated activity. In contrast, the $\mathrm{V}_{2}$ analogues did not show any effect. The slight further decrease only observed in the presence of $10^{-8} \mathrm{M} \mathrm{V}_{2}$ antagonist has already been noticed in mammals with the $\mathrm{V}_{2}$ antagonist behaving like a $V_{1}$ agonist (Ellis et al. 1994). With regard to $\mathrm{Ca}^{2+}$ accumulation, neurohypophysial peptide agonists at $10^{-8} \mathrm{M}$ revealed the following order of potency: $A V T=I T>V_{1}$ agonist $>V_{2}$ agonist. Concerning the antagonists, while the $V_{1}$ antagonist reversed significantly the AVT effect, the $V_{2}$ antagonist had no such effect.

Our results taken together (cAMP decrease, $\mathrm{Ca}^{2+}$ increase, pharmacological receptor characterization) are in favour of the presence of $\mathrm{V}_{1 \mathrm{a}}$-type receptors in trout hepatocytes. Some authors have proposed that $\mathrm{V}_{2}$-type receptors coupled with adenylate cyclase stimulation may 
also exist in fish, namely in eel liver (Moon \& Mommsen 1990) and in trout kidney (Perrott et al. 1993), although the concentrations of hormone used in their experiments were high $\left(\mathrm{D}_{\max }\right.$ between $\left.10^{-6}-10^{-5} \mathrm{M}\right)$. Our previous work on peripheral vasotocin receptors in lower vertebrates emphasized the ' $V_{1}$ ' feature of these receptors in such distinct organs as trout pituitary and gill (Guibbolini \& Lahlou 1987, Guibbolini et al. 1988, Lahlou et al. 1988, Guibbolini \& Lahlou 1990, 1992, Pierson et al. 1996). Recently, in the teleost fish Catostomus commersoni, the molecular structure of the vasotocin receptor was established by Mahlmann et al. (1994) and that of the isotocin receptor by Hausmann et al. (1995). Both AVT and IT receptors transcripts have been found in several bony fish organs (gills, liver, pituitary, lateral line). The AVT receptor presented a sequence homology with mammalian neurohypophysial hormone receptors, particularly with the rat vasopressin $\mathrm{V}_{1 \mathrm{a}}$ receptor $(60.9 \%$ identity), and to a lesser extent with the human oxytocin receptor (48\%) and rat and human vasopressin $\mathrm{V}_{2}$ receptors (about 40\%). The isotocin receptor displays the greatest similarity to the mammalian oxytocin receptor. It can be noted that the sequence homology between receptors may also explain the slight $V_{1}$ agonistic effect we observed with the $\mathrm{V}_{2}$ antagonist on trout hepatocytes. Mahlmann's study (Mahlmann et al. 1994) also showed that (1) Xenopus oocytes injected with the cloned AVT receptor-encoding cRNA respond to AVT by the induction of membrane chloride currents, (2) the AVT-induced responses are blocked, in particular, by the $\mathrm{V}_{1}$ specific antagonist, $\left[\mathrm{d}\left(\mathrm{CH}_{2}\right)_{5}{ }^{1}, \mathrm{O}-\mathrm{Me}-\mathrm{Tyr}^{2}, \mathrm{Arg}^{8}\right]$-vasopressin (the same as used in our study), and (3) the transduction of the hormonal message occurs via the phospholipase $\mathrm{C}$ and inositol phosphate/calcium pathway, usual characteristics of the $\mathrm{V}_{1}$ receptor family.

In summary, trout hepatocytes display a neurohypophysial hormone receptor which is functionally close to the $V_{1 a}$ sub-family of vasopressin receptors, as results from pharmacological and second messenger production studies support. Interestingly, the cellular signalling machinery of these cells responds equally to the two peptides, arginine vasotocin and isotocin, present in the teleostean pituitary. The present results sustain the observation that, unlike the mammalian hormones vasopressin and oxytocin, the teleost fish peptides vasotocin and isotocin have not been shown up to now to act on separate target organs and their physiological effects are usually qualitatively similar, although displaying different hormonal potencies. Functional and structural binding studies are awaited to clarify this discrepancy, so as to determine the presence of one or more neurohypophysial peptide receptors within the same target organ.

\section{Acknowledgements}

The authors are indebted to Dr B Fossat and Dr J Porthé-Nibelle for helpful advice on hepatocyte iso- lation and to Dr S Dallot for statistical expertise of data analysis.

\section{References}

Ade T, Segner H \& Hanke W 1995 Hormonal response of primary hepatocytes of the clawed toad, Xenopus laevis. Experimental and Clinical Endocrinology and Diabetes 103 21-27.

Balment RJ, Warne JM, Tierney M \& Hazon N 1993 Arginine vasotocin and fish osmoregulation. Fish Physiology and Biochemistry 11 189-194.

Berven LA, Hughes BP \& Barritt GJ 1994 A slowly ADP-ribosylated pertussis-toxin-sensitive GTP-binding regulatory protein is required for vasopressin-stimulated $\mathrm{Ca}^{2+}$ inflow in hepatocytes. Biochemical Journal 299 399-407.

Bradford MM 1976 A rapid and sensitive method for the quantitation of microgram quantities of protein utilising the principle of protein-dye binding. Analytical Biochemistry 72 248-254.

Butlen D, Ammar A \& Roseau S 1993 Pharmacological characterization of vasotocin receptors in the frog nephron. In Vasopressin, pp 574. Eds P Gross, D Richter \& GL Robertsons. Paris: John Libbey Eurotext.

Cantau B, Keppens S, De Wulf H \& Jard S $1980\left[{ }^{3} \mathrm{H}\right]$ Vasopressin binding to isolated rat hepatocytes and liver membranes: regulation by GTP and relation to glycogen phosphorylase activation. Journal of Receptor Research 1 137-168.

Cerpovicz PF \& Ochs RS 1992 Effects of EGF on the mass of inositol 1,4,5-trisphosphate and $\mathrm{SN}(1,2)$-diacylglycerol in freshly isolated rat hepatocytes: comparison with vasopressin. Biochemical and Biophysical Research Communications 187 1055-1062.

Duszynski J, Elensky M, Cheung JY, Tillotson DL \& LaNoue KF 1995 Hormone-regulated $\mathrm{Ca}^{2+}$ channel in rat hepatocytes revealed by whole cell patch clamp. Cell Calcium 18 19-29.

Ellis MJ, Mulligan RS, Evans MJ \& Donald RA 1994 The effects of corticotrophin-releasing hormone, arginine vasopressin and their antagonists on ACTH release from perifused horse anterior pituitary cells. Journal of Endocrinology 143 85-93.

Fahrenholz F, Boer R, Crause P, Fritzsch G \& Grzonka Z 1984 Interactions of vasopressin agonists and antagonists with membrane receptors. European Journal of Pharmacology 100 47-58.

Fitzgerald TJ, Uhing RJ \& Exton JH 1986 Solubilization of the vasopressin receptor from rat liver plasma membranes. The Journal of Biological Chemistry 261 16871-16877.

Garrison JC, Borland K, Florior VA \& Twible DA 1979 The role of calcium ion as a mediator of the effects of angiotensin II, catecholamines and vasopressin on the phosphorylation and activity of enzymes in isolated hepatocytes. The Journal of Biological Chemistry $2547147-7156$.

Guibbolini ME \& Lahlou B 1987 Neurohypophyseal peptide inhibition of adenylate cyclase activity in fish gills. The effect of environmental salinity. FEBS Letters 220 98-102.

Guibbolini ME \& Lahlou B 1990 Evidence for presence of a new type of neurohypophysial hormone receptor in fish gill epithelium. American Journal of Physiology 258 R3-R9.

Guibbolini ME \& Lahlou B 1992 Gi protein mediates adenylate cyclase inhibition by neurohypophyseal hormones in fish gill. Peptides 13 865-871.

Guibbolini ME, Henderson IW, Mosley W \& Lahlou B 1988 Arginine vasotocin binding to isolated branchial cells of the eel: effect of salinity. Journal of Molecular Endocrinology 1 125-130.

Hajnoczky G \& Thomas AP 1997 Minimal requirements for calcium oscillations driven by the IP3 receptor. EMBO Journal 16 3533-3543.

Hausmann H, Meyerhof W, Zwiers H, Lederis K \& Richter D 1995 Teleost isotocin receptor: structure, functional expression, mRNA distribution and phylogeny. FEBS Letters 370 227-230. 
Janssens PA, Caine AG \& Dixon JE 1983 Hormonal control of glycogenolysis and the mechanism of action of adrenaline in amphibian liver in vitro. General and Comparative Endocrinology 49 477-484.

Janssens PA, Kleineke J \& Caine AG 1986 Calcium-independent stimulation of glycogenolysis by arginine vasotocin and catecholamines in liver of the axolotl (Ambystoma mexicanum) in vitro. Journal of Endocrinology 109 75-84.

Kleineke JW \& Janssens PA 1993 Hormone-induced rise in cytosolic $\mathrm{Ca}^{2+}$ in axolotl hepatocytes: extracellular origin and control by cAMP. American Journal of Physiology 265 C1281-C1288.

Lahlou B, Fossat B, Porthé-Nibelle J, Bianchini L \& Guibbolini M 1988 Inhibitory effect of neurohypophysial peptides on cyclic AMP accumulation by isolated hepatocytes of the trout. Journal of Endocrinology 119 439-445.

Larcher A, Delarue C, Homo-Delarche F, Kikuyama S, Kupryszewski G \& Vaudry H 1992 Pharmacological characterization of vasotocin stimulation of phosphoinositide turnover in frog adrenal gland. Endocrinology 130 475-483.

Mahlmann S, Meyerhof W, Hausmann H, Heierhorst J, Schönrock C, Zwiers H, Lederis K \& Richter D 1994 Structure, function, and phylogeny of $\left[\mathrm{Arg}^{8}\right]$ vasotocin receptors from teleost fish and toad. PNAS 91 1342-1345.

Manning M \& Sawyer WH 1984 Design and uses of selective agonistic and antagonistic analogs of the neuropeptides oxytocin and vasopressin. Trends in Neurosciences 7 6-9.

Manning M, Stoev S, Chan WY \& Sawyer WH 1993 Receptorspecific antagonists of vasopressin and oxytocin. A current perspective. In The Neurohypophysis: a Window on Brain Function. Annals of the New York Academy of Sciences, vol 689, pp 219-232. Eds WG North, AM Moses \& L Shares. New York: The New York Academy of Sciences.

Moon TW \& Mommsen TP 1990 Vasoactive peptides and phenylephrine actions in isolated teleost hepatocytes. American Journal of Physiology 259 E644-E649.

Morel A, O'Carroll A-M, Brownstein MJ \& Lolait SJ 1992 Molecular cloning and expression of a rat $\mathrm{V}_{1} \mathrm{a}$ arginine vasopressin receptor. Nature 356 523-526.

Morel A, Lolait SJ \& Brownstein MJ 1993 The cloning and structure of the rat V1a AVP receptor. In Vasopressin, pp 59-68. Eds P Gross, D Richter \& GL Robertsons. Paris: John Libbey Eurotext.

Morgan NG, Shipp CC \& Exton JH 1983 Studies on the mechanism of inhibition of hepatic cAMP accumulation by vasopressin. Federation of European Biochemical Societies 163 277-281.

Morris NJ, Bushfield M, Lavan BE \& Houslay MD 1994 Multi-site phosphorylation of the inhibitory guanine nucleotide regulatory protein Gi-2 occurs in intact rat hepatocytes. Biochemical Journal 301 693-702.

Newman ME 1985 Vasopressin inhibits cyclic AMP accumulation and adenylate cyclase activity in cerebral preparations. Federation of European Biochemical Societies 181 203-206.

Pang PKT \& Furspan P 1984 The effect of arginine vasotocin on hemodynamics and urine production in the perfused trout trunk. Federation Proceedings $\mathbf{4 3} 720$.
Perrott MN, Carrick S \& Balment RJ 1991 Pituitary and plasma arginine vasotocin levels in teleost fish. General and Comparative Endocrinology 83 68-74.

Perrott MN, Sainsbury RJ \& Balment RJ 1993 Peptide hormonestimulated second messenger production in the teleostean nephron. General and Comparative Endocrinology 89 387-395.

Pierson PM, Guibbolini ME \& Lahlou B 1995a Enzyme linked immunosorbent assay for the neurohypophyseal hormones arginine vasotocin and isotocin. Journal of Immunoassay 16 $55-79$.

Pierson PM, Guibbolini ME, Mayer-Gostan N \& Lahlou B $1995 b$ ELISA measurements of vasotocin and isotocin in plasma and pituitary of the rainbow trout: effect of salinity. Peptides 16 859-865.

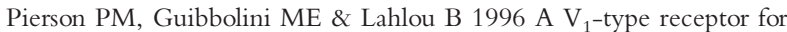
mediating the neurohypophysial hormone-induced ACTH release in trout pituitary. Journal of Endocrinology 149 109-115.

Porthé-Nibelle J \& Lahlou B 1981 Mechanisms of glucocorticoid uptake by isolated hepatocytes of the trout. Comparative Biochemistry and Physiology B 69 425-433.

Romanelli A \& Van de Werve G 1997 Activation of mitogenactivated protein kinase in freshly isolated rat hepatocytes by both a calcium- and a protein kinase C-dependent pathway. Metabolism 46 548-555.

Sato C, Liu JH, Uchihara M, Izumi N, Yauchi T, Sakaj Y, Asahina Y, Fukuma T, Takano T \& Marumo F 1992 V1-receptor mediated GSH efflux by vasopressin from rat hepatocytes. Life Sciences $\mathbf{5 1}$ $507-512$.

Tang EKY \& Houslay MD 1992 Glucagon, vasopressin and angiotensin all elicit a rapid, transient increase in hepatocyte protein kinase C activity. Biochemical Journal 283 341-346.

Thomas AP, Alexander J \& Williamson JR 1984 Relationship between inositol polyphosphate production and the increase of cytosolic free $\mathrm{Ca}^{2+}$ induced by vasopressin in isolated hepatocytes. The Journal of Biological Chemistry 259 5574-5584.

Uchiyama M \& Murakami T 1994 Effects of AVT and vascular antagonists on kidney function and smooth muscle contraction in the river lamprey, Lampetra japonica. Comparative Biochemistry and Physiology 107A 493-499.

Vanderwel M, Lum DS \& Haslam RJ 1983 Vasopressin inhibits the adenylate cyclase activity of human platelet particulate fraction through V1 receptors. Federation of European Biochemical Societies 164 340-344.

Warne JM, Hazon N, Rankin JC \& Balment RJ 1994 A radioimmunoassay for the determination of arginine vasotocin (AVT): plasma and pituitary concentrations in fresh- and seawater fish. General and Comparative Endocrinology 96 438-444.

Received 9 March 2000

Revised manuscript received 15 May 2000

Accepted 5 June 2000 